\title{
Towards a near-native speaker's pronunciation: The most challenging aspects of English pronunciation for Polish learners and ways of dealing with them: The consonants
}

\author{
ZBIGNIEW CZAJA
}

Received 9.04.2018, received in revised form 12.01.2019, accepted 17.01.2019.

\begin{abstract}
This paper is an attempt to present an overview of the most common and notorious consonant-related mispronunciations committed by Polish learners of English, which result mainly in a foreign accent, but also occasionally cause confusion or misunderstandings. Apart from identifying the errors, I will try to indicate possible sources of the "favoured" substitutions, as well as suggest a number of practical solutions to solve these errors. Making improvements in the areas discussed below is of paramount value if a near-native pronunciation is to be attained, since at the segmental level it is the consonants that are the basis of a native speaker's pronunciation. For this and other reasons, I will argue that the consonants should be given the greatest care at least by professionals such as English teachers and interpreters, whose English should be near-native not only for the benefit of their students and clients, but also for greater ease and better quality of communication among the entire English speaking community.
\end{abstract}




\title{
Keywords
}

Polish consonant replacements, typical consonant "near" equivalent changes, basis of native accent, fine-tuning of L2 accent, reducing L1 accent

\section{W kierunku rodowitej wymowy angielskiej: Największe wyzwania angielskiej wymowy dla Polaków i sposoby radzenia sobie $z$ nimi: Spółgłoski}

\begin{abstract}
Abstrakt
Celem artykułu jest przedstawienie najbardziej typowych i najczęściej popełnianych przez Polaków błędów w wymowie związanych $z$ niepoprawnym użyciem spółgłosek języka angielskiego i polskiego. Pomimo, że większość $z$ tych notorycznych „podmianek” spólgłoskowych lub ich mieszania powoduje tylko obcy akcent, to sa też i takie, które moga doprowadzić do nieporozumień. Oprócz przedstawienia i omówienia wyżej wymienionych problemów, postaram się również zdiagnozować ich przyczyny oraz zaproponować praktyczne rozwiazania. W sytuacji gdy celem uczącego się jest osiagnięcie wymowy zbliżonej do wymowy rodowitego anglika, perfekcyjne opanowanie spółgłosek staje się kluczowe, albowiem na poziomie segmentalnym to one stanowia fundament brzmienia rodowitych anglików. $Z$ tego i $z$ innych powodów przedstawionych $\mathrm{w}$ artykule, będę twierdził, że precyzyjne opanowanie spółgłosek powinno być bardzo ważnym celem przynajmniej dla nauczycieli języka angielskiego i tłumaczy, których to wymowa powinna być bliska rodowitej wymowy. Skorzystaliby na tym nie tylko ich uczniowie i klienci, ale docelowo wszyscy posługujący się językiem angielskim. Rozumienie i komunikacja staną się łatwiejsze i co za tym idzie efektywniejsze.
\end{abstract}

\section{Słowa kluczowe}

polskie podmiany angielskich spółgłosek, typowe quasi-ekwiwalentne zamiany spółgłosek, doskonalenie akcentu języka obcego, redukcja rodzimego akcentu 


\section{Introduction}

At present, with English used as a lingua franca worldwide, it is extremely important for learners to realise that apart from conveying the message intelligibly, having good pronunciation (devoid of a strong L1 accent), is also crucial for effective communication. One way of approaching this goal is by properly mastering the L2 sound system segments, which are to a large extent responsible for the quality and clarity of one's pronunciation. Good pronunciation results in less effort being required from listeners and facilitates an easier exchange of ideas.

It is common knowledge that learners of English may overlay the sounds of their native tongue onto the sounds of the L2 inventory (Dumville 1909: 10) and thus build L1 English sound "cocoons." 4 , creating L1-based accents. Polish learners are no exception and, like any other nationality, have their own "favoured" Polish-specific ways of overlaying. By using Polish "near" equivalent consonants or vowels they give their English a foreign accent and at times, when employing an incorrect or mistaken sound, they can cause confusion, misunderstandings or even communication breakdown.

Having studied the pronunciation of Polish learners of English for most of my over 30 year-long teaching career, I have arrived at the conclusion that the vast majority of their pronunciation problems appear to stem from two main sources. The first is Polish phonology, which I call the "default system" and the second is Polish phonics (rules of decoding/reading spelling). Both of these seem to be unconsciously resorted to whenever learners lack linguistic L2 knowledge or practice regarding a particular pronunciation issue. All English examples used in the paper come from observations in the

${ }^{4}$ I have coined this term to refer to nationalities speaking English with their L1 accents. In mono-lingual groups comprised of teachers and learners, communication in the L2 is easier as there are no other L2 accents involved. 
course of my professional career as an English academic teacher, teacher trainer and Cambridge ESOL examiner across all proficiency levels, in particular B2 and $\mathrm{C} 1$.

\section{Consonants in view of ELT}

In this article, I am going to concentrate solely on the English consonants with a view to two of the most common Polish problems: first, the typical fault consisting of replacing certain consonants with incorrect consonant sounds, which produces the L1 accent and potentially difficulties in comprehension. Second, I am going to focus on the "notorious" substitutions of English consonants with their Polish "near" equivalent yielding a merely foreign accent. In addition, I will briefly examine the causes of the above issues and propose some pedagogical solutions to deal with them.

To begin with, it is worth pointing out that a mastery of consonants plays a fundamental role in the pursuit of a nearnative pronunciation in any language. Contoids, being far more resistant to change and stable than vowels (Jassem 1976: 84, Wells 1982: 74, Cruttenden 1994: 65-66, O’Connor 1998: 24), seem to perform a special function in the sound system of languages, which I have come to call 'destination' or 'anchorage' points for the more "fluid" and "elusive" vowels. It must be realised that without mastering the consonants, it is not possible to attain a genuinely native sound even if somebody has successfully learnt all the English vowels. Hence, if a Polish learner applies an incorrect Polish consonant sound, e.g. the Polish velar / $/$ instead of the English / k/ in the word choir, he/she may, in addition to revealing his/her Polish accent (the English /h/ is glottal), be completely misunderstood when he/she pronounces it as / xwaje/ unless the context is sufficiently clear.

Speaking of near-native pronunciation, it should also be kept in mind that it is the most frequently occurring sounds in a language - predominantly contoids - which are responsible for the articulatory setting of that language. The 'articulatory 
basis' as it is sometimes referred to, in turn, determines the production of speech segments and adds to their particular overall sound. In the case of English, 5 these are the alveolar ridge consonants $/ \mathrm{t} /, / \mathrm{d} /, / \mathrm{s} /, / \mathrm{z} /, / \mathrm{n} /, / 1 /$ that give it its overall alveolarised sound (Honikman 1964). In Polish, the overall sound will be more dentalised since all of these consonants' 'near' equivalents are dental in Polish. ${ }^{6}$

Another reason why consonants are of such importance is that "they form the bones, the skeleton of English words and give them their basic shape" as well as the fact that "they contribute more to making English understood than vowels do" (O'Connor 1998: 24). According to Crystal (1997: 145) "in listening to speech we ignore the vowel differences e.g. the length in "cap" and "cab" and hear the consonant differences". Thus, they are fundamental for the recognition and understanding of words and as a consequence, the content of the whole utterance. "Do you like Polish?" without the vowels would still be roughly decodable to native speakers $/ \mathrm{d}_{-} \mathrm{j}_{-} 1_{-} \mathrm{k}$ p_1_/, however with the consonants left out /_U_ə_aI___əU_I _/, it would be virtually impossible to make sense of the phrase.

Finally, as regards English and Polish consonants, the statement can be risked that Polish learners generally feel more at ease with them as there are more consonants in Polish (29) than in English (24). ${ }^{7}$ As a result, they do not find it hard to assign working "near" equivalents. However, this greater confidence does not mean that consonants are not an issue. As mentioned earlier, Polish and English contoids are not identical, and while "comprehensible", the Polish quasi-

\footnotetext{
5 This will be explained in more detail in VI.

6 Unlike most phoneticians, Reszkiewicz (1981: 90) also classifies the Polish /1/ as dental, and not alveolar.

7 According to Gussmann (2007), the basic number is 29. However, others, such as Wierzchowska (1980), also include the palatalized variants in the inventory, which then results in a total of 37 consonants.
} 
equivalents sound foreign to an English ear and for that reason should be corrected. 8

Let us turn our attention now to the consonant-related errors most typical and frequently committed by Polish learners of English. From the pedagogical point of view, it is worth noting that these common mispronunciations are systematic and because of that, they may be considerably minimised if adequate attention is paid to them and practice is applied. Let us begin our review with the segments, which do not occur in the Polish sound system, and are potentially the most problematic.

\section{The most "notorious" usual consonant substitutions}

I. Replacement of /ð/ with the Polish /z/, /d/, /v/ or /dz/ (the Polish voiced dental affricate does not occur in English) results in:

a) Foreign accent: the, this, that, these, those, with, though; and of $/ \theta /$ with /s/, /t/or /f/: thousand, both, theory, thank, enthusiastic, thriller, method, thesis, authority.

b) Possible confusion: three - free, tree; through - true; thank tank - sank; think - sink; thin - fin - tin - sin; thick - tick - sick.

c) Replacement of / $\mathrm{y} /$ with the Polish nasal dental /n/ or $/ \mathrm{n} /$ especially in slow, careful speech resulting in:

c') Foreign accent: pink, sting, punk, ranking, ink, link, long (/I/ tends to be pronounced as /i/), which results in the pronunciation of the ending as /ink/ or /nk/; or /onk/ as in ping-pong / pink-ponk/.

c") Possible confusion: thin, thing - /think/; ring - / rink/; sin, sing - /sink/; win, wing - /wink/; kin, king - /kink/.

\footnotetext{
8 "The sounds of two languages may be identical, but the phonologies are different and overall sound too" (Sapir 1921: 53).
} 
As opposed to the situation twenty or thirty years ago, my teaching experience shows that the production of these English dental fricatives /ð/ and / $\theta /$ today, is not such a common and pervasive issue in Poland as it was in the past. Nowadays, most probably owing to easy access to spoken English via the radio, TV, Internet or audio recordings, most learners tend to pronounce these consonants more or less correctly. Those, however, who have still failed to master the sounds, traditionally tend to replace the $/ \theta /$ with $/ \mathrm{s} /$, or $/ \mathrm{f} /$ or even /t/, e.g. thousand, and /ð/ with /z/ or /dz/, or / or even /d/, e.g. in the article the, which does not cause major problems with understanding, but creates a foreign accent. Yet, students need to be made aware of the fact that occasionally communication problems may arise, for example, when "thick" happens to be pronounced as "sick", in which case the understanding of the message will rely heavily on the context of the utterance. So, it seems rather obvious that whilst speaking of a person's absence, it would be highly unlikely for someone to say that the person is "thick" and confusion would be avoided. Still, with the words below confusion or even misunderstanding might occur: thin - sin - tin - fin; three, free, tree. One of the most common explanations offered by teachers to students whilst describing the consonants at issue is that they are "lispy" sounds. This rather impressionistic view is hardly precise and sufficient in my opinion. The teacher needs to demonstrate the production of the sounds and follow up with a detailed description of how and where they are made, which should be followed by substantial practice. As mentioned before, the consonants / $\theta /$ and /ठ/ represented in spelling by the th letter cluster are non-existent in Polish, but rather frequent in English mostly due to the fact that they occur in high-frequency words (Cruttenden 1994: 196). ${ }^{9}$

As far as the nasal consonant /y/ (e.g. long, ranking, punk or sing) is concerned, it is occasionally, particularly in slow

9 Out of the total of $60.78 \%$ of consonants in English, / $\delta /$ occurs in 3, $56 \%$ whereas $/ \theta /$ in only $0.37 \%$ of running text. 
and careful speech, articulated as the Polish dental /n/ followed by $/ \mathrm{k} /$ due to devoicing of the final $/ \mathrm{g} /$. It is worth pointing out that the production of this nasal $/ \mathrm{y} /$ consonant is not that difficult to explain to Polish students due to the fact that the consonant at issue occurs in Polish as an allophone of the Polish /n/ in words such as tango, bank, reka 'hand', łaka 'meadow', kongres 'congress', tynk 'plaster'. Hence, if necessary, students can be referred to a relatively numerous group of such words for reference and guidance. Speaking of practice and fun, it is always challenging and revealing to learners to pronounce pairs of cognates to detect the subtle differences and resemblances in pronunciation between them in both languages e.g. tango, mango, drink, congress, bank, gang, pingpong, ranking. ${ }^{10}$

II. Replacement of $/ \mathrm{J} /, / 3 /, / \mathrm{t} \int /, / \mathrm{d}_{3} /$ with the Polish $/ \mathrm{s} /$ or $/ 6 / ; / \mathrm{z} /$ or $/ \mathrm{z} / ; / \widehat{\mathrm{tS}} /$ or $/ 6 /, / \widehat{\mathrm{dz}} /$ or $/ \mathrm{d} \bar{c} /$ respectively, resulting in:

a) Foreign accent: shop, shock, special, bush; genre, pleasure, leisure, beige; change, picture, march, church; jazz, majority, manager, fridge.

Even though the frequency of occurrence of these English post-alveolar fricatives and affricates $/ \mathrm{J} /, / 3 /, / \mathrm{t} \int /, / \mathrm{d} 3 /$, is comparatively low, ${ }^{11}$ the Polish replacements do contribute to a noticeable Polish accent. On the whole, Polish learners, at least initially, believe they have a choice as to which Polish consonant to choose. i.e. instead of $/ \mathrm{t} \int / \mathrm{as}$ in choice/ $\widehat{\mathrm{ts}} /$ or $/ \mathrm{tc} /$, for $/ \mathrm{d}_{3} /$ as in June / ब/ $/$ or $/ \mathrm{d} /$, for $/ 3 /$ as in pleasure /z/ or $/ z /$, and for $/ \mathrm{J} /$ as in shoes $/ \mathrm{s} /$ or $/ 6 /$. However as can be

10 More Polish words for reference and practice of / $\mathrm{y} /:$ franki 'francs', sęk 'knot', drag 'pole', piosenka 'song', Irenka 'little Irene', punkt 'point', szranki 'lists', bankomat 'cash machine', dżungla 'jungle', pak 'bud', strag 'pod', tynk 'plaster', cynk 'zink', tankowiec 'tanker', sukienka 'dress', budynki 'buildings'.

$11 / \mathrm{S} / 0.96 \%, / 3 / 0.10 \%, / \mathrm{t} / \mathrm{O} 0.41 \%, / \mathrm{d}_{3} / 0.60 \%$; total of $2.07 \%$ out of $60.78 \%$. 
heard, the overwhelming majority tend to apply the harder ones $/ \widehat{\mathrm{TS}} /, / \widehat{\mathrm{d}} \mathrm{J} /, / \mathrm{z} / \mathrm{l} / \mathrm{s} /$ rather than the softer consonants / to $/$, $/ \mathrm{m} /, / \mathrm{z} / \mathrm{and} / \mathrm{\sigma} /$, since the latter sound rather peculiar and amusing even to Polish learners, e.g. picture pronounced as / picie/ 'drink'. In order to sound more native, students need to be informed as early as possible that neither option is correct: the English consonants are produced in between the Polish two respective variants in terms of place of articulation (Sobkowiak 2008: 77). Thus, learners should be told that the Polish / $\widehat{\mathrm{TS}} /$ is dental-alveolar while the English $/ \mathrm{t} \int /$ is postalveolar, and the Polish /t6/ palatal; the Polish / ब/z/ is dentalalveolar, English /dz/ post-alveolar, and Polish / d/ palatal. Moreover, the Polish /s/ is dental-alveolar, English / $/$ / postalveolar, and Polish/6/ is palatal and finally, the Polish / $\mathrm{z} /$ is dental-alveolar, the English /3/ post-alveolar, and Polish /z/ is palatal. These twelve obstruents mark three different points of contact between the tip/blade of the tongue and the top teeth for the Polish $/ \widehat{\mathrm{ts}} /, / \widehat{\mathrm{dz}} /, / \mathrm{s} /, / \mathrm{z} /, 12$ the post-alveolar area for the English / $\mathrm{t} /, / \mathrm{d}_{3} /, / \mathrm{J} /, / 3 /$ (Roach 2002: 49) and finally, the hard palate for the Polish consonants $/ \mathrm{tc} /, / \mathrm{d} /$, /6/ and /z/. Even though the choice of one of the Polish variants is unlikely to stop anyone from being understood,13 they will sound unnatural and non-native to English speakers. From the pedagogical point of view, an effective and amusing way of demonstrating the differences in sound to students is to ask them to compare and practise saying the English and Polish words and sentences below, first the English way and then the Polish way: 1 . once; 2 . three times each; 3 . only Polish words and sentences; 4. only English words and sentences; 5. Polish words and sentences with the English sounds; 6. English words and sentences with both Polish sounds.

12 In my own pronunciation I feel them to be more dental-alveolar rather than alveolar as most Polish phoneticians claim (Porzuczek 2016: 31, Gussmann 2007: 6-7).

13 Usually they choose the dental-alveolar harder variants. 
1. czapa 'big cap' - chopper - ciapa 'oaf' Ale czapa! 'What a big cap!'

What a chopper!

Ale ciapa! 'What an oaf!'

2. John(ek) 'little John' - John - dzion(ek) 'little day'

Ale szczęśliwy John(ek)! 'What a happy John / Johnny!'

Ale szczęśliwy dzionek! 'What a happy little day!'

3. le że 'I'm lying' - leisure - lezie 'He's trudging along'

Ja sobie le żę. 'I'm having a lie-down.'

at leisure

'On lezie' 'He's shuffling along'

Gdzie mi tu lezie, jak ja léze?? 'Where do you think you're going?! I'm in bed.'

4. prosze 'please' - pressure - prosię 'pig'

Ależ proszę! 'By all means!'

Ależ prosię! 'What a pig !'

Prosze to prosię! 'I'll take this pig, please!'

As normally happens, Polish learners realize and learn that the English sounds 'localised' between the two Polish consonant places of articulation, though similar, are not identical. Conversely, English students learning Polish will have realized that the English consonants which they have at their disposal, are not sufficient to pronounce Polish words correctly without causing confusion. Hence, they need to master two new sounds 'situated' on both sides of their English consonants to avoid making use of their English post-alveolars to cover in each case the two Polish outwardly similar consonants. In effect they would sound more like native Polish speakers and avoid bringing about confusion or misunderstandings. For instance, Ja ciesze się/czesze sie when spoken by an Englishman who has in his segment repertoire only the sound / $\mathrm{t} /$ to substitute for the Polish / t $/$ or / TS/,would most likely be pronounced identically as / $\mathrm{t} \int \mathrm{e} \int \mathrm{\partial} /$, as in Cheshire Cat, and could be extremely confusing, not to mention amusing, to Poles who might understand it as 'I comb (my hair)' or 'I am glad'. Likewise, the question / $\mathrm{t} \int \mathrm{e} \rho \iint \partial$ ? / might be interpreted 
either as Cieszysz się meaning 'Are you glad?' or Czeszesz się? meaning 'Do you comb (your hair)?'. Fortunately, no such misunderstandings are likely to occur when any of the Polish consonants are used to 'cover' the English ones by Poles, they will only have a foreign accent, which still, in the case of professionals such as English teachers or interpreters should be reduced as much as possible. All in all, it should be stressed that confusion or misunderstandings will be more frequent and common on the English side, when English learners of Polish begin substituting the Polish 'pairs' with their English single consonants.

III. Replacement of / $/$ / with the Polish / $/$ resulting in:

a) Foreign accent: chemical, technology, chronology, technical, characteristic, architecture, chemistry, polytechnic, chorus, technique, technician, character, chronic, hierarchy, chaos, technological, choir, chronological, charisma, masochist, cholesterol, Christmas, choral.

This is a common and frequent substitution made by Poles, which clearly appears to be influenced by the Polish pronunciation of cognates which look and sound similar. Students' attention needs to be constantly drawn to the fact that the English letter cluster ch is never pronounced as /h/ or the Polish velar / $\mathrm{x} /$, but predominantly as / $\mathrm{t} /$ / e.g. chair, bachelor, lunch, or as $/ \mathrm{k} /$ shown in the words above. Although it is undeniably tempting and effortless to resort to something learners already know, like reading ch as / h/ from Polish instead of embarking upon a new learning process, students should be encouraged to stay alert and to check their pronunciation whenever they encounter words spelt with $c h$. It is important that students realise this small detail might upgrade their English accent considerably if they only remembered to make the switch from $/ \mathrm{x} /$ to $/ \mathrm{k} /$. In this way, fewer instances of voiceless friction (so characteristic of a Polish accent) would be produced. Learners should be 
reminded that the letter cluster ch is never realized in English as the Polish $/ \mathrm{x} / ; / \mathrm{k} /$ or $/ \mathrm{t} /$ are the only available options. Polish phonics, according to which $c h$ is read as $/ x /$, must not be carelessly followed. Finally, a word of caution: beware of the possible mispronunciation of the word chore, which when pronounced the Polish way with / $\mathrm{x} /$ might sound like whore.

IV. Replacement of / s/ with the Polish / t $\widehat{s} /$ or /sts/ resulting in:

a) Foreign accent: certificate, concentrate, specific, fascinating, participate, concert, discipline, scenario, pharmacist, scenery, recipe, scissors, recession, cinema, facilitate, accept, decision, specialist, process, centre, cylinder, deficit, city, civic, cigar, receipt, pharmacy.

Another common pronunciation error of Polish learners is the replacement of the English consonant sound /s/ with the Polish consonant / $\mathrm{t} / \mathrm{s} /$ or even pronouncing both sounds one after the other /st $/$ / when the spelling so indicates. Again, in both cases the main cause of the erroneous pronunciations seems to be the spelling. When listening to Polish learners mispronouncing words in this way, it is evident to a Polish native speaker that they simply follow Polish phonics rules when pronouncing English words, ignoring or rather failing to apply the English possibilities (English phonics). Another possible reason for this issue might be the Polish pronunciation of cognates. Everyone tends to resort to this strategy, automatically and frequently adopting the L1 pronunciation as correct in the L2. This approach, which relies upon learners' guesses without recourse to a dictionary check, often leads to the adoption of 'approximate' pronunciations, which become fossilized and extremely difficult to eradicate later on. As regards possible solutions, Polish students should be continually reminded that the letter $c$ is never read as / t $\widehat{\mathrm{s}} /$ as it is in Polish, but is typically read as / k/ e.g. Canada, coca cola, cross or as the sound /s/ as in the examples above. It 
needs to be stressed that nowadays, with computer and online dictionaries available, checking the pronunciation of new words immediately should become a fixed routine for learners to avoid 'inventing' their 'approximate' Polish pronunciations. In addition, learners must be made aware of the fact that there are innumerable cognates in English and Polish, whose pronunciations are deceptive and misleading, e.g. the word alibi is pronounced in Polish /a'libi/ and in English /'æləbar/; region /'regjon/ in English /'ri:dzən/; minister /mi'nister/ in English /'ministə/, analysis is /a'nælisis/ and not /ana'lizis/, diploma is /dip'lormə/ in English, not /'diplom/ etc. Because of this, such words should immediately alert students in terms of possible problems with pronunciation.

V. Replacement of /s/ with the Polish / z/ resulting in:

a) Foreign accent: 1) crisis, exclusive, basis, inclusive, isolated, fantasy, emphasis, disappear, leasing, increasing, useless, closer, execute, ecstasy, releasing, base, philosophy, dishonest, use-noun, loose, episode, analysis, disappointing, disagree, curiosity, decreasing, comparison, hypnosis, thesis, isolate, isolation, philosophical, advertisement, purchasing, oasis, insist, consist, consist, mus(t)n't, facebook, baseball.

The next common consonant replacement "notoriously" used by Poles is the English consonant /s/ substituted with the Polish /z/. It must be stressed that this switch might be fairly surprising and somewhat unexpected to an English ear from Poles, and therefore, learners' attention should be drawn to it and action should be taken to eradicate it as soon as possible. It paradoxically creates a foreign, non-Polish accent and, to native speakers, which is perceived predominantly as 'hissy and rustley' in sound, on account of the general tendency of Polish learners to devoice rather than voice. As for the causes of this 'unexpected' substitution, it appears obvious that this time the source of the error is not the spelling. As can be seen, in the majority of the cases in group a), the $/ z /$ voicing 
happens in the intervocalic position, which might suggest that voiceless consonants should be voiced in this environment. This however, does not prove to be justified since Polish phonology permits both voiceless and voiced consonants in mid-word position e.g. pasuje 'fits', pozuje 'poses', nasuwa 'prompts', nazywa 'calls'. The main cause of this type of mispronunciation seems to be the Polish pronunciation of cognates where $/ z /$ is used instead /s/ e.g. extasy/ekstaza, crisis/kryzys, basis/baza. Another possible explanation could be that Polish learners incorrectly extend the Polish rule concerning compulsory consonant cluster voicing agreement, ${ }^{14}$ which does not apply in English. Accordingly, voicing occurs and produces a foreign accent. As for corrective tips, a useful exercise is asking learners to say some Polish words in which they have to replace the medial /s/ with / $z /$. This allows them to experience how 'odd' such a substitution sounds to native speakers, e.g. posada 'position', masywny 'massive', zasuwać, 'to dash along', kasować 'punch (a ticket)', prasować 'to iron'. 15 This unnatural pronunciation for northern Poland (from where the author originates) enables learners to understand how English people might feel when they mispronounce such words in this way.

By way of explanation, it needs to be pointed out that a small set of words exists in which the opposite foreign accent marking process described later in section IX takes place, where loss of voicing occurs. This set is composed of a very limited number of cognates whose Polish pronunciation involves /s/ and the English /z/ e.g. cosmetic, cosmos, cosmopolitan, cosmology, resort, cosmonaut, which is misleading to a Polish learner. Moreover, it is also worth

14 The second sound in a cluster determines the presence or absence of voicing in the preceding consonant, e.g. in the word podgrupa 'subgroup' the voiced /g/ keeps the /d/ voiced, but in podstawa 'basis', the voiceless /s/ makes the preceding /d/ into a voiceless /t/. Consequently, the "Polish" pronunciations of baseball, blackbird and football will contain the clusters /zb/, /gb/ and / db/ respectively instead of / sb/, / kb/ and / tb/.

15 In Southern Polish though, such voicing is encountered e.g. poszlismy 'we went', wygraliśmy 'we won', byliśmy 'we were', $\mathbf{s} L D$ 'Alliance of Democratic Socialists', jeśli 'if'. 
mentioning that with some words both pronunciations / $z$ / or /s / are acceptable e.g. exit, absurd, dishonest or Muslim, 16 but this appears to be a regional accent feature - in the standard English of southern Britain it is more common to apply the /s/ pronunciations.

As far as pedagogy is concerned, learners must be made aware of the problems and advised to opt for the safer "northern Polish" pronunciation with /s/ to keep the RP accent consistent, even when two possibilities exist. This /s/ to $/ z /$ switch is also common among Indian speakers of English, which Polish students find amusing to listen to, and therefore may be a factor in whether or not they choose to use it.

VI. Replacement of the alveolar ridge consonants / $\mathrm{n}, \mathrm{t}, \mathrm{d}, \mathrm{s}, \mathrm{l}$, $z /$ with their Polish dental near-equivalents resulting in:

a) Foreign accent

As mentioned earlier, one of the key changes regarding consonants that Polish students should remember to make, but frequently fail to implement, is to move the articulation of the Polish sounds $/ \mathbf{n}, \mathbf{t}, \mathbf{d}, \mathbf{s}, \mathbf{1}, \mathbf{z} /{ }^{17}$ from the upper teeth to the alveolar ridge. This location is the most vital place of articulation for English and learners should be made aware of it at the earliest possible opportunity. These English alveolar consonants (except when /t/ and /d/ are followed by /r/ in which case, they become post-alveolar) are the most frequently occurring consonants in English, which along with the most common vowels / , I, e, aI, $\Lambda$, eI / (Cruttenden 1994: 136, from Fry 1947) constitute the basis of the English Articulatory setting (Honikman 1964: 76). 18 Although their Polish dentalisation does not bring about a change in meaning, it

16 Both /s/ or /z/ possible: disgrace, dismiss, forensic, fantasy, exit, dishonest, translate, absurd, dismay, disorder, prosodic, Islamic, Muslim, persist, visa, resource, absorb.

17 I have included /1/ as a dental lateral in Polish after Reszkiewicz (1981: 90). I have observed that the way I pronounce is also more dental.

18 Honikman includes also the post-alveolar " $r$ " consonant in this group. 
clearly creates English with a Polish accent. Indeed, it must be remembered that English native pronunciation is imbued with alveolarisation, which results from the default position of the speech organs, adopted to produce fluent and comfortable English speech (Honikman 1964). For this very reason, it is of the utmost importance to familiarise students with the notion of the articulatory setting for English, as a prerequisite for being able to attain a near-native sound. The articulatory setting could be compared to the foundations of a house, upon which the remaining elements will be built.

Let us look at some exercises and activities which can be conducted to help students become more precise in their pronunciation and to set the lips, tongue and jaw in the English way. The words below contain alveolar ridge sounds to allow students to realise that in English the tongue is held higher in the mouth and that most of the time it hits the alveolar ridge, not the top teeth as in Polish. In order to practise this raised position of the tongue, students should try to practise saying the words first vertically and then horizontally a few times, making sure that the tongue is kept against the alveolar ridge and not the upper teeth.

a) Words

$\begin{array}{llllll}\text { 1.turn } & \text { 1. sin } & \text { 1. lawn } & \text { 1. none } & \text { 1.zone } & \text { 1.dine } \\ \text { 2. tide } & \text { 2. said } & \text { 2. load } & \text { 2. nod } & \text { 2. zoomed } & \text { 2.did } \\ \text { 3. toss } & \text { 3. cease } & \text { 3. less } & \text { 3. nurse } & \text { 3. Zeus } & \text { 3.dos } \\ \text { 4. tease } & \text { 4. says } & \text { 4. lose } & \text { 4. knees } & \text { 4. zoos } & \text { 4. does } \\ \text { 5. tight } & \text { 5. sat } & \text { 5. late } & \text { 5. note } & \text { 5. zest } & \text { 5. dart } \\ \text { 6. tool } & \text { 6. soul } & \text { 6. lull } & \text { 6. nil } & \text { 6. zeal } & \text { 6. doll }\end{array}$

Having given the students a taste of how unnatural it feels for Polish speakers to keep the tongue from falling lower, they can move on to phrase and then sentence level conducting group and individual practice to allow students to experience the differences between the English and Polish renditions. 
b) Phrases

1. ten lists

2. ten tents

3. ten dentists

4. ten trains

5. ten strains

6. twenty solicitors

7. twenty runners

8. twenty lessons

9. twenty zoos

10. twenty dances

c) Sentences

1. No, never. No, I don't know.

2. Ted spends the nights out whenever he likes to.

3 . Look at those ten dolls on the zoo lawn.

4. Don't tell Don about the sales.

5. Liz wanted to support us, but she didn't know how to do it.

6. Let's talk about the latest trends in science now.

VII. Replacement of $/ \mathrm{r} /$ with the Polish $/ \mathrm{r} /$ and readiness to pronounce it when the letter " $r$ " occurs resulting in:

a) Foreign accent or non-RP accent: e.g. iron, bar, aren't, poured, effort, Irish, weren't, important, word, irony, teacher, park, sort, occur, war.

The sound / r/ seems to be the only English consonant which varies in sound quality between different native accents. Although the Polish / $\mathrm{r} /$, an alveolar trill, is not as dramatically different in sound from the English / $\mathrm{r}$ / (post alveolar flap) as e.g. the French or German / $/$, there is no doubt that when it is made the Polish way it sounds foreign to an English ear. Polish learners especially at lower levels, guided by the English spelling and Polish phonics tend to pronounce the letter " $r$ " in final and even in pre-consonantal position, e.g. iron /ajron/ or in bar /bar/ not lengthening the vowel /a/ in the latter, thus sounding more American-like. This strategy may also be caused to some degree by the fact that in Polish there are no long vowels, which in English non-rhotic accents compensate 
the pronunciation of the /r/, e.g. important / Im'po:tont/. Some learners, on the other hand, may be simply afraid of saying /im'potent/ meaning impotent instead, and therefore to be on the safe side, they decide to pronounce the " $r$ ". For pedagogy, students have to be immediately sensitised to the fact that in $\mathrm{RP}$ "r"s are not pronounced in such contexts and that the tongue for the production of the English / $\mathrm{r} /$ is further back in the post alveolar region, not on the teeth ridge as for Polish. Additionally, learners have to become used to the idea that words such as law and lore, paw and pore, caught and court are homophones in which the "r"s are silent. Paradoxically, a problem of the opposite nature arises when, in fast connected speech, they should pronounce the linking and intrusive / $/ \mathrm{r}$, which even high level students fail to do, e.g. over and over again and China / $r$ / and America.

VIII. Replacement of the aspirated voiceless plosives $\left[\mathrm{p}^{\mathrm{h}}, \mathrm{t}^{\mathrm{h}}, \mathrm{k}^{\mathrm{h}}\right]$ with Polish un-aspirated equivalents $/ \mathrm{p}, \mathrm{t}, \mathrm{k} /$ resulting in:

a) Foreign accent: e.g. pop, pot, park, paper, tight, top, talk, totter, cook, cup, cat, kicking.

Polish learners of English should remember that aspirated consonants are/sound longer and require greater force of articulation (Wells 1982: 75; Reszkiewicz 1981: 63). In spite of the fact that there are some accents in the British Isles which do not use aspiration at least on these word initial plosives, mainly Scotland and Northern England (Catford 1988: 204, Wells 1982: 74), Polish learners of English would benefit remarkably in terms of a near-native RP accent if only the changes described above were successfully mastered and applied. If RP is the goal, it is worth trying to produce these sounds because they are not numerous and could be relatively easily implemented to the satisfaction of both sides of the communication process - the students themselves would sound more English and the English listener would comprehend them more readily. My experience shows that 
especially the initial ' $t$ ' fails to be aspirated by Polish students, as in words such as tennis and tenis, test and test, ten and ten 'this' sound identical in Polish. Because of this, students feel amused when they have to produce the words first in the English aspirated way ('spitting' they say) and then the Polish non-aspirated way and then alternately savouring the discrepancies. Ultimately, students should say them correctly and notice the difference in the accent they have acquired. The pairs of words below work equally well in making students aware of the idea of a foreign accent as well as the importance of reducing it for ease of communication.

a) Words

\begin{tabular}{|c|c|}
\hline 1. tattoo & to tu 'it's here' \\
\hline tuck & tak 'yes' \\
\hline talk & tok 'course' \\
\hline 2. Poland & Polska \\
\hline pasta & pasta 'polish' \\
\hline pot & pot 'sweat' \\
\hline 3. cry & kraj 'country' \\
\hline car & kara 'punishment' \\
\hline cop & kop 'dig, kick' \\
\hline
\end{tabular}

b) Phrases and sentences

1. Twenty two tigers

2. Take the train today

3. Peter and Polly Pickering

4. Post the parcel to Penny

5. Chris and Christina Craig

6. Cross the country carefully

7. Paul and Kate Thomas

8. Two cats in the park

9. Please, talk to Karen

10. What's the matter with this particular computer? 
IX. Replacement of final /b/, /d/, /g/, /v/, /z/, /ds/, /3/ and/ð/ with /p/, /t/, /k/, /f/, /s/, / t /, / $/ \mathrm{f}$ and $/ \theta /$ or corresponding Polish "near"-equivalents /p/, /t/, /k/, /f/, /s/, $/ \widetilde{\mathrm{tS}} /, \mathrm{s} / \mathrm{and} / \mathrm{t}, \mathrm{f}, \mathrm{s} /$ resulting in:

a) A foreign accent: club, rob, web; friend, word, wind; big, leg, fog; wave, drive, move; nose, is, choose; change, fridge, judge; beige, rouge, collage; bathe, paths, clothes.

b) Confusion or misunderstanding: pub/pup, mob/mop, robe/rope; seed/seat, rude/root, code/coat; log/lock, clog/clock; pig/pick; live/life, love/laugh, save/safe; lose/loose, raise/race; eyes/ice; badge/batch, ridge/rich, cadge/catch.

Interestingly, in English there are extremely few words ending in /3/ and not many finishing in / d / , therefore even when the last consonant becomes substantially devoiced communication is not threatened, only an accent is created. On the other hand, English has an abundance of pairs ending in $/ \mathrm{z} /$ and $/ \mathrm{s} /, / \mathrm{d} /$ and $/ \mathrm{t} /$ and $/ \mathrm{g} /$ and $/ \mathrm{k} /$ potentially causing confusion or misunderstandings. In the examples that follow, the problem for Poles is to keep the voiced consonants voiced or at least partially voiced, since when completely devoiced the Polish way, a different word is likely to be produced.

\section{a) Sentences}

1. Watch your knees!

2. My eyes!

3 . Is this your code?

4. It's a log.

5. I like the cub.

$\begin{array}{ll}\text { sounds like } & \text { Watch your niece! } \\ \text { sounds like } & \text { My ice! } \\ \text { sounds like } & \text { Is this your coat? } \\ \text { sounds like } & \text { It's a lock. } \\ \text { sounds like } & \text { I like the cup. }\end{array}$

sounds like Watch your niece! sounds like My ice! sounds like Is this your coat? sounds like I like the cup.

The problem of losing voicing in the final position is pervasive and heavily impacts the area of English grammatical endings, i.e. voiced plural endings: pots, rugs, matches; third person 
singular voiced verb endings: he jumps, he plays, he messes and possessive endings: Pete's, Jane's, George's. This is also an issue with voiced simple past regular verb endings /d/, /id/, as in begged, lived, robbed /d/ and wanted, needed, rented/Id/, which tend to be pronounced as /t/ and /it/ respectively. It is commonly known, however, that Polish learners have no problems with the pronunciation of the unvoiced English endings as in walked, worked, booked pronounced as / $t$ / when they follow the rules of Polish phonology. When it comes to devoicing final obstruents, this normally shows the domino effect leading from one problem to the next, i.e. in the word bed when the final /d/ is devoiced to /t/ the plural ending / $\mathrm{z} /$ also becomes devoiced, and consequently the word beds becomes pronounced as /bets/, which, when spoken by a Pole, sounds identical to bets. The same phenomenon is highly likely to occur with words such as dock/dog, rice/rise or pup/pub and this also may lead to confusion or misunderstandings in some situations. By devoicing the final sound of the base word, we automatically devoice its grammatical ending, and the message may become obscured. For instance, the pronunciation of the word wait poses no problem, but that of waited does, since the ending tends to be devoiced to / $\mathrm{kt} /$. However, in the word need the problem begins earlier, i.e. the final sound /d/ pronounced as /t/ yields /ni:t/. When the "ed" marker is attached to it, the devoicing issue moves on to the last sound /d/, which becomes / $\mathrm{t}$ / whilst the / $\mathrm{d}$ / from need is again properly voiced. It is fairly evident that Polish speakers simply follow Polish phonology here so it is always the final voiced consonant that bears the brunt of being devoiced, not the median one.

It is worth noting that due to these Polish-based habitual devoicing issues the overall sound of Polish-accented English is somewhat 'hissy' and 'muffled' when compared to the more 'vocal' and 'buzzy' overall sound of English. ${ }^{19}$ This impression

\footnotetext{
19 "The voiceless sounds [...] break up the stream of voice with fleeting moments of silence [...] approximately every 4-5th sound is voiceless" (Sapir 1921: 49).
} 
was aptly described by Oscar Wilde who said of Polish "I can hear hissing, rustling and hushing and my ears are bleeding". In Polglish 20 this is a pervasive 'global' problem as Sobkowiak (2008: 57) calls it, and it has to be tackled intensively and practised extensively at every opportunity.

In terms of practical solutions, an amusing technique for explaining the difference in sound between the two languages is to tell students that the English sound more like bees and their speech is buzzing, whereas Polish people sound like snakes and they tend to "hiss" and "rustle" like leaves when they speak. Another entertaining and effective teaching idea for giving Polish learners a taste of how they sound to an English ear with all the devoicing in place, is to ask them to read Polish words and sentences in which voiced consonants (at least in mid position, not initial) are devoiced, e.g. podrzemałem sobie 'I had a nap' /potszemałem sobie/, pozmywajcie talerze 'wash the plates' / posmyfajcie talesze/, nie ma nikogo nade mna 'there's no one above me' / nie ma nikoko nate mna/, bardzo przyzwoicie 'decent work' / barco przysfoicie/. This convincingly and amusingly shows Polish learners how it feels to be on the receiving end when too much devoicing is produced. Even though most ${ }^{21}$ of it is intelligible though "muffled" in sound, over time it can become irritating to a native speaker.

\section{Conclusions}

As our review has shown, nearly all of the consonant replacements made by Polish learners of English mostly cause a foreign accent with occasional confusion or misunderstanding. The only errors which may sporadically cause

\footnotetext{
20 In English continuous speech voicing makes up a greater proportion of utterance than voicelessness and it is also the case with most Western European Languages. The ratio of voiced to voiceless sounds: French 78/22, English 72/28, Polish 64/36, Russian 61/39 (Catford cited in Laver 1994: 194).

${ }^{21}$ Podrzemałem with the devoiced / $\widehat{d} \mathrm{~d} /$ to /s/may sound like potrzymałem 'I held/kept'.
} 
misunderstanding are $/ \theta /$ and $/ \delta /$ in section $I$ and $/ z /, / g /$ and $/ \mathrm{b} /$ in section IX. The latter substitutions when devoicing comes into play, happen to be frequently pronounced identically to the words with originally voiceless consonants at the end and hence depending on the context confusion or possibly a misunderstanding may occur e.g. dies/dice; dog/dock; said/set. It should be stressed that appropriately made consonants give the English of non-native speakers a near-native speaker quality and refined sound. Since consonants are a fundamental component of near-native pronunciation, the non-native speaker has to be fully aware that a native accent cannot be attained without mastering the consonants even when the vowels are perfectly articulated. Although consonants take native children much longer to master, they stay with them for good, while vowels may be replaced at will, e.g. when native speakers move to a different part of the English speaking world or else, to a different job, which requires them to change their accent. To put it simply, if an English native speaker wishes to change his accent, he only has to learn the new vowels whereas a non-native must master both the L2 new vowels to "convey the meaning" and the L2 consonants to refine his accent. Even if it is true that for the majority of English learners the L1 quasi-equivalent consonants suffice for intelligible communication, it must be emphasized that professionals such as teachers and interpreters should aim higher and make every effort to master the consonants to a near-native standard. This will enable them to be a good model for students and make communication in translation smooth, stress-free and enjoyable.

Bearing in mind the fact that every language is unique in terms of its sound inventory (Sapir 1921: 46, Catford 1988: 188, Abercrombie 1967: 70), which includes the quantity and quality of the "vocal building blocks", suprasegmentals (stress, rhythm and melody patterns) and phonological rules unconsciously acquired by native speakers ("the glue for joining the building blocks"), L1 elements ought to be avoided while speaking English if near-native sound and ease of 
communication are the goals. Therefore, I agree with Daniel Jones when he says that when people try to speak each other people's languages in a way that is pleasant to those people, ${ }^{22}$ it enhances the communication act itself, not to mention the satisfaction, high self-esteem and confidence the learners gain from it (Kenworthy 1987: 12).

Finally, it should be stressed that good English pronunciation is possible to master if learners genuinely care about how they sound, and are determined and prepared to regularly work hard on it. ${ }^{23}$ As Aristotle stated, "Excellence [...] is not an act but a habit". Numerous examples among a number of my colleagues and some students demonstrate that even at a later age near-native pronunciation can be achieved. It must be kept in mind that pronunciation is not something that one can leave to learn later, with priority being given to other aspects of language. Incorrect habits of pronunciation, which gradually develop while learners concentrate on the message (grammar and vocabulary) without paying equal attention to accurate pronunciation, quickly become deeply rooted and extremely difficult to eradicate. Moreover, it should be remembered that learning correct pronunciation is a long-term and ongoing process consisting of constant improvements and modifications to one's performance. This process could be compared to native children learning and gradually perfecting the sound system and phonology of their L1 during the initial five or six years of their lives. Gimson and Cruttenden (1994: 96) claim that vowels take up to two and a half years to master while Crystal (1997: 240) maintains that they are finally fixed by the age of four.

22 "I gradually came to see that phonetics had an important bearing on human relations - that when people of different nations pronounce each other's languages really well (even when the vocabulary and grammar are not perfect), it has an astonishing effect on bringing them together, it puts people on terms of equality, a good understanding between them immediately springs up" (Fromkin et al. 2003: 231).

23 "And make no mistake, your aim must be to acquire a perfect English pronunciation" (O`Connor 1998: 5). But, as Jassem (1976: 97) states, this cannot be achieved without hard regular work. 
In this paper I have tried to show that the two major causes of pronunciation errors regarding the consonants are Polish phonology being used as a default system, and the combination of English spelling and Polish phonics, to which learners naturally resort when short of linguistic knowledge. Although this paper deals only with the most common consonant-related difficulties of Polish learners, I believe that English spoken by Poles would improve considerably in terms of attaining a near-native accent if Polish learners were made aware of these pronunciation problems and then practised correcting them extensively perhaps initially by taking advantage of some of the teaching ideas suggested in this paper. Despite the fact that Polish learners on the whole do not develop such conspicuous accents as Spanish, Italian or French learners, they could still make themselves understood more easily by improving their pronunciation of consonants and, consequently, make their contribution to international communication more effective. As for other nationalities, they might also work on their L1 consonantal problems leaving their "L1 cocoons" for the benefit of better international communication in English, so that when faced with other nonnative English speakers they would have fewer comprehension problems.

Ultimately, we must not forget that good pronunciation is a prerequisite for effective and enjoyable spoken communication. It is like neat handwriting for written communication, therefore it is worth improving, as it guarantees satisfaction on both sides of the communication act.

\section{References}

Abercrombie, David (1967). Elements of General Phonetics. Edinburgh: Edinburgh University Press.

Catford, John. C. (1988). A Practical Introduction to Phonetics. Oxford: Clarendon Press. 
Cruttenden, Alan (ed.) (1994). Gimson's Pronunciation of English. 5th edition, revised and edited version of Alfred. C. Gimson's original book. London: Edward Arnold.

Crystal, David (1997). The Cambridge Encyclopedia of Language. 2nd edition, Cambridge: Cambridge University Press.

Dumville, Benjamin (1909). The Science of Speech. 2nd edition 1926. London: University Tutorial Press.

Fromkin, Victoria, Nina Hyams, Robert Rodman (2003). Introduction to Language. 7th edition. Fort Worth: Harcourt Brace College Publishers.

Gussmann, Edmund (2007). The Phonology of Polish. Oxford: Oxford University Press.

Honikman, Beatrice (1964). "Articulatory settings". In: D. Abercrombie, D. B. Fry, P. A. D. MacCarthy, N. C. Scott, J. L. M. Trim (eds.). In Honour of Daniel Jones: Papers Contributed on the Occasion of His Eightieth Birthday 12 September 1961. London: Longmans, Green \& Co. Ltd., 73-84.

Jassem, Wiktor (1976). Fonetyka języka angielskiego. Warszawa: Państwowe Wydawnictwo Naukowe.

Kenworthy, Joanne (1987). Teaching English Pronunciation. London: Longman.

Laver, John (1994). Principles of Phonetics. Cambridge: Cambridge University Press.

O'Connor, John D. (1998). Better English Pronunciation. 12th edition. Cambridge: Cambridge University Press.

Porzuczek, Andrzej, Arkadiusz Rojczyk, Janusz Arabski (2016). Praktyczny kurs wymowy angielskiej dla Polaków. Katowice: Wydawnictwo Uniwersytetu Ślaskiego.

Reszkiewicz, Alfred (1981). Correct Your English Pronunciation. 12th edition. Warszawa: Państwowe Wydawnictwo Naukowe.

Roach, Peter (2002). English Phonetics and Phonology. Cambridge: Cambridge University Press.

Sapir, Edward (1921). Language: An Introduction to the Study of Speech. Harcourt: Brace and World.

Sobkowiak, Włodzimierz (2008). English Phonetics for Poles. Poznań: Wydawnictwo Poznańskie.

Wells, John C. (1982). Accents of English 1: An Introduction. Cambridge: Cambridge University Press.

Wierzchowska, Bożena (1980). Fonetyka i fonologia języka polskiego. Warszawa: Polska Akademia Nauk. 
Zbigniew Czaja

ORCID iD: 0000-0002-7505-9029

Instytut Anglistyki i Amerykanistyki

Uniwersytet Gdański

ul. Wita Stwosza 51

80-308 Gdańsk

Poland

z.czaja@ug.edu.pl 